\title{
Investigating the adoption of TPACK-21CL by English pre-service teachers in a COVID-19 teaching practicum
}

\author{
Nur Arifah Drajati*, Hilda Rakerda, Hefy Sulistyawati, Joko Nurkamto, and \\ Ma'rifatul IImi \\ English Education Department, Universitas Sebelas Maret, Surakarta, Jl. Ir Sutami No. 36, Kentingan, \\ Kec. Jebres, Kota Surakarta, Jawa Tengah 57126, Indonesia
}

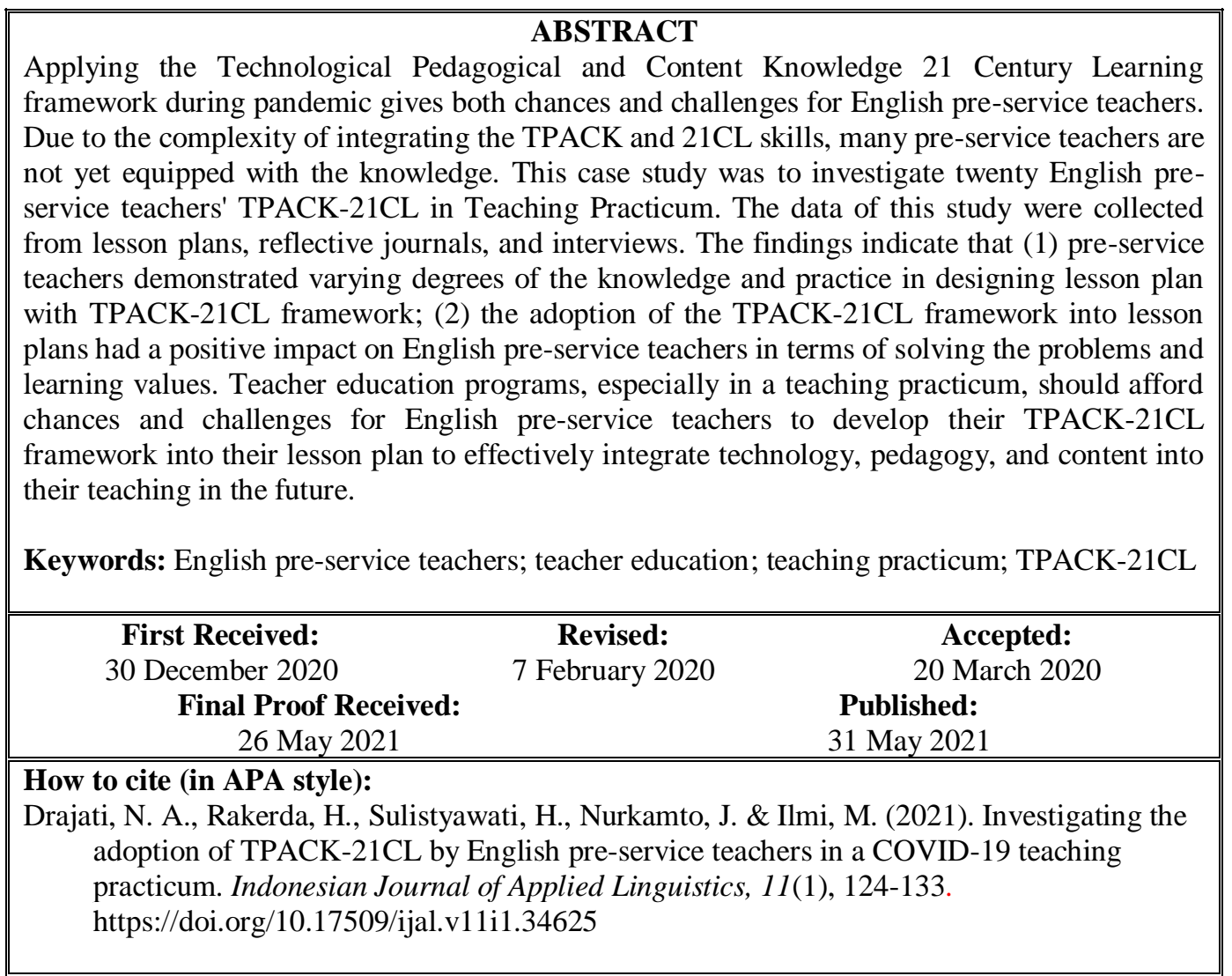

\section{INTRODUCTION}

Twenty-first-century learning (21CL) can be viewed as learning experiences that engage students in fostering sociocultural, cognitive, metacognitive, productive, and technological competencies to function in a 21st-century workplace (Koh et al., 2016; Koh et al., 2015). In language education, teachers need to have a specialized form of professional knowledge termed as technological pedagogical content knowledge (TPACK) to support ICT integration (Mishra \& Koehler, 2006) into routine curriculum practices, such as language materials design instruction and assessment.

TPACK is an essential knowledge dimension that English pre-service teachers must acquire and develop teaching skills in initial teacher education. The seven aspects are TK, PK, CK, PCK, TCK, TPK, and TPACK, which need to be explored by initial teachers to integrate technology into their teaching language. However, many pre-service teachers have problems in designing lesson plans and practicing the integration of pedagogy, content, and technology in the classrooms. Pre-service teachers get challenges and difficulties in understanding, designing, and implementing lessons with technology integrated into the classroom (Aşık et al., 2020; Baser et al., 2016; Mouza et al., 2017; Zipke, 2018).

\footnotetext{
*Corresponding Author

Email: nurarifah_drajati@staff.uns.ac.id
} 
English pre-service teachers need a form for learning in terms of technology integrated with pedagogical and content knowledge. The TPACK framework initiated by Mishra and Koehler (2006) needs to be taught to pre-service teachers as the initial learning experience before becoming teachers at schools. At the same time, English pre-service teachers need to learn 21st-century skills: communication, creative thinking, collaboration, problem-solving, and digital literacy. Koh et al. (2016) proposed several formulations for scaffolding the TPACK framework for teachers and defining it with TPACK-21 Century Learning (TPACK-21CL). The concept of the TPACK-21CL was developed with rubrics and design heuristics. In the previous study, Koh et al. (2016) reported one year of research implementing the rubric of TPACK-21CL with Singaporean in-service teachers. The result had a positive impact on the teachers in practicing lessons and students' learning output. Kola (2019) reported his action research that South African pre-service teachers should first comprehend the content and instructional design before teaching practice integrated with technology.

This study aims to adopt the TPACK-21CL model for English pre-service teachers through the lesson plan, reflective journal, and interview. The TPACK-21CL for English pre-service teachers conducted in teaching practicum for 16 weeks, a semester-long course.

\section{TPACK}

The main conceptual framework for TPACK in the education area is based on the ideas in the articles by Mishra and Koehler (2006) about the core aspects of teacher's knowledge for effective teaching, namely knowledge of content, pedagogy, and technology. Content knowledge (CK) is teacher's knowledge about the subject matter to be taught, pedagogical knowledge (PK) refers to teacher's knowledge about methods, strategies, and practices of teaching and learning, while technological knowledge (TK) is teacher's knowledge of modern technologies including computer and internet. In addition, there is also the interaction and interplay between those three areas. The integration between knowledge of pedagogy and content creates an overlapping area of pedagogical content knowledge (PCK) built based on Shulman's (1986) idea on strategies of teaching specific content. Knowledge of technology and pedagogy interacts to form technological pedagogical knowledge (TPK), referring to how technology can support pedagogical goals. Knowledge of technology and content interacts to form technological content knowledge (TCK), referring to how subject matter can be transformed through the use of technology. Finally, the new, integrated knowledge that goes beyond the individual core elements of content, pedagogy, and technology and the PCK, TPK, and TCK, is realized as technological, pedagogical content knowledge (TPACK), as seen in Figure 1. In TPACK, teachers understand how to use different and appropriate technologies for different pedagogical goals in delivering content or subject matter effectively to students. Hence, this model is called the integrative model of TPACK (Koehler et al., 2007; Koehler \& Mishra, 2009; Mishra \& Koehler, 2006).

\section{Figure 1}

TPACK Framework (Mishra \& Koehler, 2006)

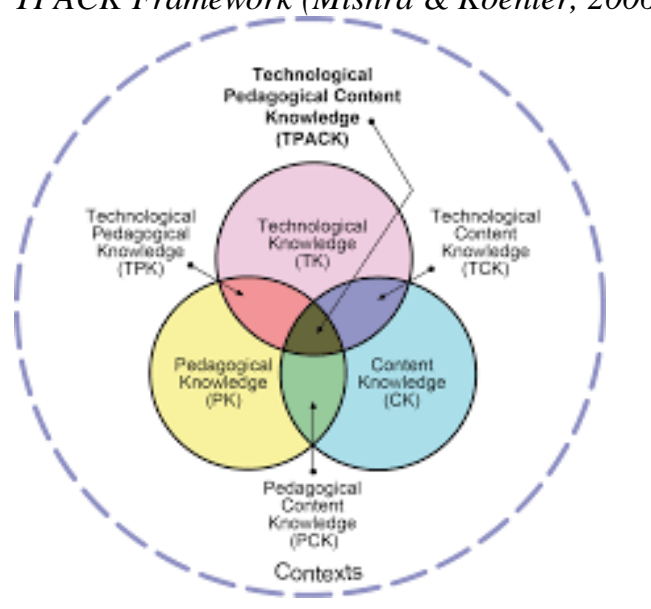

Research on TPACK has been growing in numbers and content areas such as Science, Mathematics, and Social Sciences (Oz, 2015) in education using different research methodologies, mainly quantitative or mixed-method approaches. A literature review study was done by Wang et al. (2018), aiming to synthesize TPACK-related research for pre-service teachers in 2006-2015. The study concluded that more and more research used more than one research method over time, while recurring patterns were gained from those studies. First, modeling by teacher educators or in-service teachers is critical for developing pre-service teachers' TPACK knowledge; second, how these studies indicated and reported the development of the seven domains of TPACK by English preservice teachers.

Quantitative longitudinal research assessed the development and change of pre-service teachers' TPACK during their three-year education program in universities in Finland. The research yielded a conclusion that pedagogical content knowledge (PCK) was the most significant gain (Valtonen et al., 2019). Correlational research using multiple regression analyses by Shinas et al. (2015) also investigated the development of pre-service teachers' TPACK after receiving technology preparation during their initial licensure program. The study revealed that individual knowledge is a significant factor for pre-service teachers. Mixedmethod research was conducted by $\mathrm{Oz}$ (2015) to assess the TPACK knowledge of pre-service 
teachers in a language education program in Turkey. It was revealed that the pre-service teachers obtained a high level of TPACK knowledge from faculty members during their study, even though TPACK was not fully practiced to obtain L2 outcomes due to a possible lack of TPACK knowledge from their cooperating teachers. Therefore, the study reported in this paper used a different perspective of research methodology by carrying out a case study for a deeper and more comprehensive exploration of the use of TPACK in the EFL education context.

Besides the application of different research methodologies, the aforementioned studies focused on developing pre-service teachers' TPACK knowledge without relating it with other issues in education, such as the relevance of TPACK with pre-service teachers achieving skills other than the three core areas of pedagogy, content, and technology, particularly in the recent COVID-19 situation. One of the significant developments of the TPACK concept is its relation with the so-called 21st-century learning skills, which are the skills required of students to succeed in information and technology. According to Voogt and Roblin (2012), in the context of 21st-century learning skills, TPACK is relevant for students to acquire sociocultural, cognitive, metacognitive, productivity, and technological skills, so that the teaching-learning process must be directed to the acquisition of these skills. The integration of ICTbased activities can help teachers get students engaged in learning experiences to collaborate, communicate, resolve conflicts, think critically for problem-solving, do self-reflection and selflearning, and manage efficient and practical work.

Technology-based and meaningful learning provides five dimensions to which 21 st-century learning is realized. Research by Howland et al. (2013) and Kozma and Anderson (2002) suggest the dimensions of students' active learning using ICT to experiment with information; students' meaningful learning and high order thinking using ICT; students' monitoring learning achievement using ICT; students' engagement in authentic problem solving through the use of ICT; and students' collaborative learning using ICT. Those studies imply that it is paramount that students must engage in active, constructive, meaningful, and collaborative learning to obtain 21 st-century skills. For example, during the current COVID-19 pandemic era, both teachers and students are forced to drastically change the practice of teaching and learning from face-to-face to online mode. It is a major challenge for teachers to select materials, plan learning tasks, implement teaching, and assess students through online learning using different platforms and media. Thus the ICT skill is one of the most crucial skills that teachers must master to teach effectively. Meanwhile, for students, the challenge brought about by such a never-before situation lies in the fact that teachers' guidance in teaching-learning sessions may lessen to a minimum level so that students must use their ICT skill to seek actively, comprehend, analyze and evaluate the materials that their teachers give through different web-based sources and media.

The English pre-service teachers, as future teachers, certainly need to do professional development to teach and facilitate their students in acquiring the 21st-century skills, as previously mentioned. Koh (2013) mentioned five critical aspects of how TPACK-21CL is developed through teacher professional development: codesign experiences, pedagogical orientation, opportunities for implementation, opportunities for reflection, and evaluation of teacher and student outcomes. In codesigning experiences, English pre-service teachers construct and evaluate their teaching practices; in setting pedagogical orientation, they examine their current pedagogical practices against those of 21st-century learning; in the third aspect, opportunities for implementation, English preservice teachers are given the opportunities to implement the ICT lesson designs for 21 st-century learning. In opportunities for reflection, pre-service teachers engage in reflection of their 21 st-century learning design experiences, whereas in the evaluation of teacher and student outcomes, English pre-service teachers comprehensively evaluate student outcomes and teacher's confidence in designing lessons and implementing 21st-century learning practices.

In assessing the English pre-service teachers' use of TPACK-21CL in their teaching practicum, this study used Koh's (2016) TPACK-21CL adaptation of rubric to assess to what extent the English pre-service teachers used ICT-based media in their teaching practice. The rubric assessed these aspects: a. the activeness of both teachers and students using ICT concerning content delivery; $b$. the constructiveness of students synthesizing and processing multimodal language expressions using ICT; c. the level of authenticity of the real-world phenomenon being presented and solved using ICT; d. the level of the intentionality of using ICT for students' self-reflection; and e. the collaborative experiences of students using ICT to work on divergent knowledge. The scoring ranges from 0 for the minimum use of ICT-based media or technology to 4 for the optimized use of technology.

\section{METHOD \\ In this study, we used a case study methodology as the researchers can have complexity and intensity in getting and exploring the knowledge and information on the subject matter. Specifically, the case study related to English pre-service teachers' participants in learning and applying TPACK-21CL.}


The case study methodology was used since this methodology makes it possible to obtain indepth knowledge of the subject matter and examine the study problems in every aspect (Merriam, 1998). The embedded case study was mainly applied, and the 'case' was English pre-service teachers' TPACK (Technological Pedagogical Content Knowledge) in the teaching practicum.

Twenty English pre-service teachers (sixteen females and four males) aged between 20-22 years old took a teaching practicum course and volunteered to participate in this study. It was the first time for them to learn about the TPACK framework and knowledge about 21 century learning. They took the course for preparation before taking teaching practice at schools. They also finished a fundamental technology course focusing on the necessary knowledge and technology theory for education.

In the teaching practicum course, 16 weeks, the English pre-service teachers learned the TPACK-21CL framework, the concept, and practical matters. The activities were divided into two parts since there was a COVID 19 Pandemic. The first part was Study from School' (SFC) in six meetings, and the second part was 'Study from Home' (SFH) in ten meetings. In the first part, they learned and discussed the TPACK, the 21st Century Learning concepts, and the high school syllabus. Then, they created lesson plans based on the TPACK-21CL framework. In designing a lesson plan, pre-service teachers considered the points of the TPACK-21CL: active, constructive, authentic, intentional, and collaborative. The lesson plans were discussed between student-student and lecturer-students. They revised the lesson plans from the peer's and lecturer's feedback based on the TPACK-21CL framework (Koh et al., 2016). In the second part, they implemented the lesson plan in the online classrooms. Pre-service teachers helped school teachers in conducting remote teaching (3-4 meetings, 30-45 minutes each meeting).

The data of this study were collected from preservice teachers' lesson plans, reflective journals, and interviews. The English pre-service teachers wrote diaries and reflected on their online teaching experience with the TPACK-21CL framework, their problems and challenges in teaching with designed lessons, and how to solve the problems and the teaching values. Pre-service teachers had an indepth interview to validate the reflection they wrote in their diaries.

The data analysis of this study used Content Analysis Approach (Weber, 1990). The lesson plans were analyzed by five key points: active, constructive, authentic, intentional, and collaborative in learning and teaching with the TPACK-21CL framework. The reflections were analyzed through three key points: values, problems and challenges, and solutions. The reflective journals were analyzed thematically to find the preservice teachers' challenges and the learning values.

\section{FINDINGS}

The English pre-service teachers' lesson plan evaluation based on aspects of TPACK $21^{\text {st }} \mathbf{C L}$

The English pre-service teachers' lesson plan and teaching reflection were analyzed based on the TPACK-21 CL framework (Koh, 2016) in their online course. The English pre-service teachers had to create lesson plans to show their capability in designing TPACK-21CL activities after their lecturer taught them about technology, pedagogy, and content of English material based on the TPACK 21st CL framework. As noted earlier, the lesson plan analysis tool (TPACK-21 CL rubric) included five key dimensions, and the reflection analysis was done based on the content analysis.

The English pre-service teachers' plan to implement active activities integrated with technology toward teaching English

The first aspect of TPACK-21 CL assessed in the English pre-service teachers' lesson plan was their students' active activities using ICT tools in the learning process. The active aspect involved the students' learning activities such as small group discussion, students' peer-reviewing between students-students and students-teacher. The results related to the English pre-service teachers' plan to implement active activities integrated with technology usage in the classroom are shown in Table

\section{1.}

Table 1

The English Pre-Service Teachers Plan to Implement Active Learning Activities with Technology in the Class.

\begin{tabular}{clc}
\hline Criteria & \multicolumn{1}{c}{ Indicator } & $\begin{array}{c}\text { Number of } \\
\text { Lesson Plan }\end{array}$ \\
\hline 0 & English pre-service teachers use media or ICT to transmit content all the time & 0 \\
1 & Students use ICT tools occasionally & 0 \\
2 & Students use ICT tools 50\% of the time & 12 \\
3 & Students use ICT tools more than 50\% of the time but not all the time & 8 \\
4 & Students use ICT all the time & 0 \\
\hline & \multicolumn{1}{c}{ Mean score } & $\mathbf{2 . 6}$ \\
\hline
\end{tabular}

The findings related to the English pre-service teachers' plans to enact active activities using ICT tools, obtained from the researchers' evaluation of English pre-service teachers' lesson plans using the 
TPACK-21 CL rubric, are shown in Table 1. In terms of implementing active activities using ICT tools, the English pre-service teachers received an average score of 2,6. There were twelve lesson plans shown that they had led their students to use ICT tools half of the learning time, and eight lesson plans shown that they had led the students to use it most of the learning time. They facilitated students' activities by using Educandy, Nearpod, Book Creator, Padlet, Quizizz, Ms Sway, Wattpad, Canva, FreeMind, and Voice Thread.

The first assertion that emerged from the result was that the students could not $100 \%$ construct their knowledge by themselves since the English preservice teacher still put intervention in its process. However, the English pre-service teacher needed to search for activities that let the students stimulate and reinforce their conceptual understanding of course material by engaging them within the lesson process and doing their work by using ICT all the time. For example, the teacher gave instructions to the students to discuss an object by preparing some website links for the students in searching some information related to the object, describing it with their peers, and presenting the result in the classroom.

\section{The English pre-service teachers' plan to implement constructive activities in the class} The second aspect of TPACK-21 CL assessed in the English pre-service teachers' lesson plans was their students' constructive activities using ICT tools in the learning process. The constructive aspect involved activities where ICT tools support students in making meaning, engaging in higherorder thinking as they manipulate information, articulating what they have accomplished, and reflecting on their activity. The results related to the English pre-service teachers' plan to enact constructive activities with technology toward teaching English are shown in Table 2.

Table 2

The English Pre-Service Teachers' Plan to Implement Constructive Activities Integrated with Technology Usage in the Class

\begin{tabular}{llc}
\hline Criteria & \multicolumn{1}{c}{ Indicator } & $\begin{array}{c}\text { Number of } \\
\text { Lesson Plan }\end{array}$ \\
\hline 0 & English pre-service teachers use ICT tools to transmit content & 0 \\
1 & $\begin{array}{l}\text { Students use ICT tools to engage in the content reproduction } \\
\text { Students use ICT to go beyond content reproduction but mainly still articulate }\end{array}$ & 0 \\
& $\begin{array}{l}\text { convergent knowledge } \\
\text { Students use ICT tools to synthesize information and to construct verbal, written, } \\
\text { visual, conceptual, product-oriented expressions of the learning content }\end{array}$ & 8 \\
4 & $\begin{array}{l}\text { Students use ICT tools, as described in level 3. They also articulate personal reflections } \\
\text { or application of the learning content }\end{array}$ & 4 \\
\hline Mean score & & $\mathbf{2 . 8}$ \\
\hline
\end{tabular}

The findings related to the English preservice teachers' plan to enact constructive activities using ICT tools, obtained from the researchers' evaluation of English pre-service teachers' lesson plans using the TPACK-21 CL rubric, are shown in Table 2 . In terms of the plan to enact constructive activities using ICT tools, the English pre-service teachers received an average score of 2.8. There were eight lesson plans shown that they had designed the activities where ICT tools had supported the students to articulate their knowledge through content reproduction in the same format. There were eight lesson plans shown that ICT tools had supported the student to seek information until product-oriented expressions of the learning in a different form. Four lesson plans showed that ICT tools had supported the students in seeking information and producing something such as digital stories and reflecting the students' experience in learning and creating it. The first assertion that emerged from the result was that the English pre-service teacher had a relatively good amount of knowledge to design constructive activities using ICT tools.

\section{The English pre-service teachers' ${ }^{\text {plan }}$ to present authentic material with technology usage}

The third aspect of TPACK-21 CL assessed in the English pre-service teachers' lesson plan was the authentic material using ICT tools in the learning process. Authentic aspects described real-world tasks to explain phenomena in a natural context so students could practice using those ideas in real-life contexts. The results related to the English preservice teachers' plan to present authentic material with technology usage are shown in Table 3.

The findings related to the English pre-service teachers' plan to present authentic material using ICT tools, obtained from the researchers' evaluation of the English pre-service teachers' lesson plans using the TPACK-21 CL rubric, are shown Table 3. In terms of the plan to present authentic material using ICT tools, the English pre-service teachers received an average score of 2.4. There were sixteen lesson plans shown that ICT tools only provided information about the real-world phenomenon, and four lesson plans showed that the students had engaged in the real-world cases/scenarios to support 
their learning using ICT tools. The first assertion that emerged from the result was that English preservice teachers demanded an adequate amount of knowledge to embed real-life tasks using ICT tools in their lesson design, such as describing the object around the students' environment, enriching the information by related websites, and rewriting the object facilitated by an application such as Nearpod.

Table 3

The English Pre-Service Teachers Plan to Present Authenticity with Technology Usage

\begin{tabular}{|c|c|c|}
\hline Criteria & Indicator & $\begin{array}{c}\text { Number of } \\
\text { Lesson Plan }\end{array}$ \\
\hline 0 & Real-world phenomena or problems are not being presented with media or ICT. & 0 \\
\hline 1 & $\begin{array}{l}\text { Real-world phenomenon or problems are presented with media or ICT tools by the } \\
\text { English pre-service teachers. }\end{array}$ & 0 \\
\hline 2 & Students integrate and understand real-world phenomena or problems with ICT tools. & 16 \\
\hline 3 & $\begin{array}{l}\text { Students use ICT tools more than } 50 \% \text { of the time, but not all real-world problems or } \\
\text { phenomena are used as scenarios or cases, and students use ICT tools to support the } \\
\text { creation of solutions to resolve these scenarios or cases. }\end{array}$ & 0 \\
\hline \multirow[t]{2}{*}{4} & $\begin{array}{l}\text { Students work on real-world problems or phenomena, as outlined in level } 3 \text { and present } \\
\text { their personal experiences or reflections of the real-world phenomenon or problem. }\end{array}$ & 4 \\
\hline & Mean score & 2.4 \\
\hline
\end{tabular}

The English pre-service teachers' plan to create intentional activities integrated with the class

The fourth aspect of TPACK-21 CL assessed in the English pre-service teachers' lesson plan was their students' intentional activities using ICT tools in the learning process. Intentional aspects included activities directed to the students' own learning goal. The results related to the English pre-service teachers' plan to create intentional activities using ICT tools were shown in Table 4.

Table 4

The English Pre-Service Teachers' Plan to Create Intentional Activities Integrated with Technology Usage in the Class

\begin{tabular}{|c|c|c|}
\hline Criteria & Indicator & $\begin{array}{l}\text { Number of } \\
\text { Lesson Plan }\end{array}$ \\
\hline 0 & ICT tools are not used to support students to diagnose their learning apps & 0 \\
\hline 1 & English pre-service teachers and peers use ICT tools to provide feedback to students & 0 \\
\hline 2 & Students use ICT tools or resources as a way to self-evaluate their performance & 4 \\
\hline 3 & $\begin{array}{l}\text { Students use ICT tools or resources to perform self-evaluation and obtain feedback from } \\
\text { teachers and peers through ICT platforms. Students then consolidate the feedback to improve } \\
\text { their performance. }\end{array}$ & 0 \\
\hline 4 & $\begin{array}{l}\text { Students continually use ICT tools or resources for self-evaluation and as a source of English } \\
\text { pre-service teachers or peer feedback to improve their performance }\end{array}$ & 16 \\
\hline & Mean score & 3.6 \\
\hline
\end{tabular}

The findings related to the English preservice teachers' plan to create intentional activities integrated with ICT tools, obtained from the researchers' evaluation of English pre-service teachers' lesson plans using the TPACK-21 CL rubric, are shown Table 4 . In terms of creating intentional activities using ICT tools, the English pre-service teachers received an average score of 3.6. Four lesson plans showed that they had chosen ICT tools in providing a self-evaluation source that students used to evaluate their performance. Sixteen lesson plans show that they had chosen ICT tools in providing a selfevaluation platform to evaluate their performance and obtain feedback from English pre-service teachers and peers directly. The first assertion that emerged from the result was that most English pre-service teachers knew to integrate ICT tools and the students' self-evaluation activities to know the students' intention toward the material learned. The example of self-evaluation is when the teacher gave a rubric to the students to do self-reviewing of the task and do peer-reviewing with friends facilitated by Google Docs.

The English pre-service teachers' plan to create collaborative activities integrated with technology usage in the class

The fifth aspect of TPACK-21 CL assessed in the English pre-service teachers' lesson plan was their students' collaborative activities using ICT tools in the learning process. The collaborative aspect included the activities in which the students work together in learning and knowledge-building communities, such as creating digital stories facilitated by Ebook Creator, exploiting each other's skills, such as giving reviews and comments mediated by Google Docs. The results related to the teachers' plan to create collaborative activities integrated with technology usage in the class are shown in Table 5. 
Table 5

The English Pre-Service Teachers Plan to Create Collaborative Activities in the Class

\begin{tabular}{clc}
\hline Criteria & \multicolumn{1}{c}{ Indicator } & $\begin{array}{c}\text { Number of } \\
\text { Lesson Plan }\end{array}$ \\
\hline 0 & $\begin{array}{l}\text { No collaborative activity (e.g., online discussion) occurs with ICT platforms or } \\
\text { tools }\end{array}$ & 0 \\
1 & $\begin{array}{l}\text { Students work on content reproduction activities either around the computer or } \\
\text { through the computer }\end{array}$ & 0 \\
2 & $\begin{array}{l}\text { Students work on tasks that go beyond content reproduction but mainly involve } \\
\text { convergent expressions when working together around the computer or through } \\
\text { the computer }\end{array}$ & 0 \\
3 & $\begin{array}{l}\text { Students work together either around the computer or through the computer in } \\
\text { activities requiring some degree of divergent knowledge expression } \\
\text { Students work together either around the computer or through the computer in } \\
\text { activities requiring primarily divergent knowledge expression }\end{array}$ & 12 \\
\hline & \multicolumn{1}{c}{ Mean score } & 3.6 \\
\hline
\end{tabular}

The findings related to the English pre-service teachers' plan to create collaborative activities using ICT tools, obtained from the researchers' evaluation of English pre-service teachers' lesson plans using the TPACK-21 CL rubric, are shown in Table 5. In terms of creating collaborative activities using ICT tools, the English pre-service teachers received an average score of 3.6. There were eight lesson plans shown that the students worked together and divided the task based on the degree of divergent knowledge expressions (focused merely on some topics), and there were twelve lesson plans shown that the students worked together and divided the tasks based on primarily divergent knowledge expressions (focused on interdisciplinary topics). This result shows that the English pre-service teacher had created collaborative activities integrated with technology usage toward teaching English where the students work on tasks beyond content reproduction but mainly involve divergent expressions (varieties of activities and topics) and working together around or through the computer.

\section{English pre-service teachers' reflection in designing and enacting TPACK-21CL framework}

The English pre-service teachers' reflections in designing lesson plans based on the TPACK-21CL framework and implementing it in the online classroom were categorized according to two themes: how English pre-service teachers solved the problem during the implementation and the learning values from the TPACK-21CL.

\section{Solving the problem during the implementation}

A common problem found when English pre-service teachers enacted the lesson plan is their students' readiness for online learning. The students' insufficient knowledge about the ICT tools and poor internet connection distracted the English preservice teacher instructional learning plan to make the students actively engaged/participated in the online course and did the intentional learning activities in the real-world case. For example, some students frequently left the class due to a lost internet connection during the online discussion or practicing the material. One of the English preservice teachers said, "motivating all students to keep joining the class and expecting independent learning initiatives from them during the pandemic was difficult since my students frequently left my online class and did not try to come back" (English Pre-service Teacher 1).

Besides, the English pre-service teachers frequently interrupted the learning process because of the students' inadequate skill to use the new technology application. It impacted students' willingness to fulfil the task given autonomously or to assess students' progress. One of the participants said, "My students could not finish their task on time since they felt it was so hard to use the new application, so I prepared extra time because they need extra guidance" (English Pre-service Teacher 10). The English pre-service teachers provided students with multiple familiar and simple asynchronous applications such as email and Google Form to anticipate the first teaching plan failure. The participant reported, "I used WhatsApp group and email first as an alternative to my online learning if I found it difficult to use the sophisticated application in directing my students" (English Preservice Teacher 10).

\section{The learning value from the TPACK-21CL lesson plan designing process}

During the TPACK 21CL designing process, the English pre-service teachers were motivated to learn new technological tools that they had never used before (Educandy, Nearpod, Book Creator, Padlet, Quizizz, Ms Sway, Wattpad, Canva, FreeMind, Voice Tread), and they learned to develop pedagogical integration skills. It also contributed to the English pre-service teachers' deep understanding and awareness about reuniting the gap between the ICT tools, pedagogy, and content in various ways by engaging them in designing the lesson and testing it in the real field. One of them said that "Now, I got the idea of TPACK $21 C L$ when I designed the lesson plan" (English Pre-service Teacher 18). The others said, "I positioned myself as a student. I used myself as the lesson plan parameter to make the 
learning simple to do" (English Pre-service Teacher 8).

\section{DISCUSSION}

The TPACK-21CL rubric by Koh $(2016,2013)$ was adopted in the present study to investigate English pre-service teachers' adoption of TPACK-21CL framework in the lesson plan for Teaching Practicum activity. The results showed that adopting the TPACK-21CL framework into their lesson plan positively impacted their knowledge improvement regarding teaching with ICT. Furthermore, the English pre-service teachers' knowledge and practice of the TPACK-21CL framework in the lesson plan varied. There are five concerned dimensions (active, constructive, authentic, intentional, and collaborative) of the TPACK-21CL framework being observed in the present study to investigate English pre-service teachers' TPACK21CL, as explained below:

\section{ICT-based active learning activities}

The study results implied that English pre-service teachers could design active learning activities and had implemented them in the Teaching Practicum activity with technological aids. From the lesson plan analysis, the active dimension received an average score of 2.6. In other words, the English pre-service teachers could encourage their students to learn and work with ICT integration most of the learning time. Unfortunately, the English pre-service teachers required more knowledge to design active learning activities requiring students to use ICT during their learning. This means that the English pre-service teachers' knowledge concerning the active learning design stays below 4 - the highest level of TPACK-21CL knowledge.

Tondeur et al. (2017) found two types of English pre-service teachers' ICT competency: (1) utilizing ICT to facilitate students' learning and (2) utilizing ICT to aid their only teaching. Pointing out to the current study results, the present study's findings are in line with the previous study that English pre-service teachers could use ICT for either supporting their students' learning or their teaching, in the pre-service teacher's study, needed more time, knowledge, and ledge, experiences to design and practice ICT-based active learning activities. Students would actively engage themselves in the learning activities when teachers include new and challenging activities in the learning process (Carr et al., 2015). In contrast, the current study results implied that the English pre-service teachers needed more research on learning activities that may encourage the students' active engagement during the teaching and learning process.

\section{ICT-based constructive activities}

The study results revealed that English pre-service teachers could design constructive activities and had implemented them in the Teaching Practicum activity with technology mediation. From the lesson plan analysis, this dimension received an average score of 2.8. Mostly, the English pre-service teachers allowed their students to utilize ICT tools to synthesize and construct ideas based on the converged content knowledge. Only a few of them encourage the students to go beyond content reproduction, such as personal reflection. Briefly, the English pre-service teachers' knowledge of designing constructive activities vary ranging from level 2 to 4 .

Chi (2009) claimed that there are two characteristics of constructive activities applicable in a classroom. The first characteristic is that constructive activities require students to have 'overt output' (p.78). The second characteristic is requiring students to go beyond material presentation. The finding of the current research, unfortunately, has not met these characteristics. Koh et al. (2016) further described that constructive activities need designs and redesigns and more practice to enhance their involvement in a learning process. Regarding the present study results, the English pre-service teachers lacked knowledge of the wide access and coverage of ICT that might facilitate their teaching and learning process. Thus, further refinement of such knowledge is needed.

\section{ICT-based authentic materials}

The study results revealed that English pre-service teachers had included real-world phenomena within their subject matter and utilized the ICT tools as the medium. From the lesson plan analysis, this dimension received an average score of 2.4. Although the real-world phenomena have been included, almost all English pre-service teachers used ICT tools only as the media to understand the phenomena. Instead, they could include the students' personal or daily experience to activate students' competency through ICT utilization. Indeed, the English pre-service teachers' knowledge, specifically using authentic materials, still needed more enhancement.

This dimension has a very close relation to the previous one - constructive activity. Koh et al. (2016) further explained that authentic material included within the subject matter is significant in supporting other dimensions of TPACK-21CL. It further activates students' ability to self-assessment. However, the current research found that the English pre-service teachers did not benefit from integrating ICT tools to work more with the authentic materials. The integration of ICT into teaching would be an excellent chance to support students' ability in problem-solving. Such activities can be carried out while including authentic-based problem-solving activities both synchronously and asynchronously. 


\section{ICT-based intentional activities}

Unlike the previous three dimensions, the intentional dimension is likely to receive a higher average score of 3.6. Most English pre-service teachers could utilize the use of ICT tools to provide feedback for performance improvement. Only a few used ICT tools as the media of self-evaluation. In other words, the English pre-service teachers' intentional dimension of integrating the ICT tools has developed better. This finding seems to support Shinas et al. (2015), who claim that TPK is proven to be impactful for TPACK development. In other words, the English pre-service teachers are required to learn technology as a united construct to achieve effective teaching, mainly started by considering responses and self-evaluation.

Another crucial matter in technology integration into teaching is the teachers' readiness (Shinas et al., 2015). Tondeur et al. (2017) argued that teachers' "quality and quantity" technological knowledge is essential to develop their knowledge of technology pedagogy and content matter (p. 9). Considering the current study result, the pre-service English teachers' intentionality in ICT-based teaching has represented their preparedness to teach using technological aids. Though taking the benefits from ICT tools is not an easy thing to do (Valtonen et al., 2019), these English pre-service teachers have moved forward to understand TPACK-21CL by realizing how many benefits could be gathered from ICT integrated teaching.

\section{ICT-based collaborative activities}

Like the previous dimension, the collaborative dimension also received a higher average score from the lesson plan analysis. This implied that the English pre-service teachers could see the divergent knowledge of their students and collaborate with them using the ICT medium. It was considered that teaching could improve students' performance (AlRahmi \& Zeki, 2017). Besides, Le et al. (2017) found that there are possible problems encountered while applying collaborative learning faced by both teachers and students. Utilizing the ICT tools in teaching allows students to learn in a more complex learning environment and practice team-based tasks that stimulate them to be more productive (Koh et al., 2016). The current research results implied that the English pre-service teachers had included the collaborative activities allowing their students to share their prior knowledge through the ICT tools.

Overall, the present study has contributed insightful knowledge concerning the adoption of TPACK-21CL seen from the lesson plan designed. TPACK-21CL mainly concerns five dimensions that correlate one and others. These dimensions help teachers create more meaningful learning by activating students' active engagement (Koh et al., 2016). Further, students can construct ideas and go beyond content reproduction through constructive and intentional activities. Later, students can learn sociocultural knowledge while collaborating with peers to create solutions to real-world problems. Such a construct allows students to improve their performance and achieve their learning goals. Overall, the current research findings have shown that English pre-service teachers still need more support, knowledge, and experience to improve three out of five dimensions of TPACK-21CL: active, constructive, and authentic dimensions.

\section{CONCLUSION}

This research evaluated the quality of the English pre-service teachers' lesson plans and explored their reflections in designing and implementing the TPACK-21CL framework. This research reiterated the importance of educational institutions' framework practice to prepare English pre-service teachers' teaching skills in school. The teacher educator should provide the TPACK-21CL concept and skills to produce qualified teachers toward the 21-century learning requirement as early as possible. The research results suggested periodic evaluation and feedback on English pre-service teachers' artifacts toward their TPACK capability. Broader research in more than artifacts provides better English pre-service teachers' TPACK-21CL capability.

\section{REFERENCES}

Al-Rahmi, W. M., \& Zeki, A. M. (2017). A model of using social media for collaborative learning to enhance learners' performance on learning. Journal of King Saud University-Computer and Information Sciences, 29(4), 526-535. https://doi.org/10.1016/j.jksuci.2016.09.002

Aşık, A., Köse, S., Ekşi, G. Y., Seferoğlu, G., Pereira, R., \& Ekiert, M. (2020). ICT integration in English language teacher education: insights from Turkey, Portugal, and Poland. Computer Assisted Language Learning, 33(7), 708-731. https://doi.org/10.1080/09588221.2019.158874 4

Baser, D., Kopcha, T. J., \& Ozden, M. Y. (2016) Developing a technological pedagogical content knowledge (TPACK) assessment for English pre-service teachers learning to teach English as a foreign language. Computer Assisted Language Learning, 29(4), 749-764. https://doi.org/10.1080/09588221.2015.104745 6

Carr, R., Palmer, S., \& Hagel, P. (2015). Active learning: The importance of developing a comprehensive measure. Active Learning in Higher Education, 16(3), 173-186. https://doi.org/10.1177/1469787415589529

Chi, M. T. (2009). Active-constructive-interactive: A conceptual framework for differentiating 
learning activities. Topics in cognitive science, 1(1), 73-105. https://doi.org/10.1111/j.17568765.2008. 01005.x

Howland, J. L., Jonassen, D., \& Marra, R. M. (2013). Meaningful learning with technology (4th ed). Pearson Higher Education.

Koehler, M. J., Mishra, P., \& Yahya, K. (2007). Tracing the development of teacher knowledge in a design seminar: Integrating content, pedagogy, and technology. Computers and Education, 49(3), 740-762. https://doi.org/10.1016/j.compedu.2005.11.012

Koehler, M. J., \& Mishra, P. (2008). The handbook of technological pedagogical content knowledge for educators. Routledge.

Koehler, M. J., \& Mishra, P. (2009). What is technological pedagogical content knowledge? Contemporary Issues in Technology and Teacher Education, 9(1), 60-70. https://doi.org/10.1007/978-1-4899-8080-9

Koh, J. H. L., Chai, C. S., \& Lim, W. Y. (2016). Teacher professional development for TPACK-21CL: Effects on teacher ICT integration and student outcomes. Journal of Educational Computing Research, 55(2), 172196. https://doi.org/10.1177/0735633116656848.

Koh, J. H. L. (2013). A rubric to analyze teachers' conceptions of meaningful learning in ICT lesson planning. Australasian Journal of Educational Technology, 29(6), 887-900. https://doi.org/10.14742/ajet.228

Koh, J. H .L., Chai, C. S., Wong, B., \& Hong, H. (2015). Design thinking for education: Conceptions and applications in teaching and learning. Springer Singapore, (2015), 1-131. https://doi.org/10.1007/978-981-287-444-3

Kola, M. (2019). English pre-service teachers' action research: Technology education lesson planning in a South African University. Educational Action Research, 29(1), 99-117. https://doi.org/10.1080/09650792.2019.168604 3

Kozma, R. B., \& Anderson, R. E. (2002). Qualitative case studies of innovative pedagogical practices using ICT. Journal of Computer Assisted Learning, 18(4), 387-394. https://doi.org/10.1046/j.02664909.2002.00250.doc.x

Merriam, S. B. (1998). Qualitative research and case study applications in education. JosseyBass Publishers.

Mishra, P., \& Koehler. M. J. (2006). Technological pedagogical content knowledge: A framework for teacher knowledge. Teachers College Record, 108(6), 1017-1054. https://doi.org/10.1111/j.1467-

9620.2006.00684.x

Mouza, C., Nandakumar, R., Ozden, S. Y., \& Karchmer-Klein, R. (2017). A longitudinal examination of preservice teachers' technological pedagogical content knowledge in the context of undergraduate teacher education. Action in Teacher Education, 39(2), 153-171. https://doi.org/10.1080/01626620.2016.124830 1

Oz, H. (2015). Assessing preservice English as a foreign language teachers' technological pedagogical content knowledge. International Education Studies, 8(5), 175-182. https://doi.org/10.1016/j.compedu.2012.10.008

Shulman, L. S. (1986). Those who understand; Knowledge growth in teaching. Educational Researcher, 15(2), 4-14. https://doi.org/10.3102/0013189x015002004

Tondeur, J., Aesaert, K., Pynoo, B., van Braak, J., Fraeyman, N., \& Erstad, O. (2017). Developing a validated instrument to measure English pre-service teachers' ICT competencies: Meeting the demands of the $21^{\text {st }}$ century. British Journal of Educational Technology, 48(2), 462-472. https://doi.org/10.1111/bjet.12380

Wang, W., Schmidt, D., \& Jin, Y. (2018). Preservice teachers' TPACK development: A review of literature. Journal of Digital Learning in Teacher Education, 34(4), 234258. https://doi.org/10.1080/215329 74.2018.1498039

Weber, R. P. (1990). Basic content analysis. Sage Publications.

Valtonen, T., Sointu, E., Kukkonen, J., Makitalo, K., Hoang, N., Hakkinen, P., \& Tondeur, J. (2019). Examining English pre-service teachers' technological pedagogical content knowledge as evolving knowledge domains: A longitudinal approach. Journal of Computer Assisted Learning, 35(4), 491-502. https://doi.org/10.1111/jcal.12353

Voogt, J., \& Roblin, N. P. (2012). A comparative analysis of international frameworks for 21 stcentury competencies: Implications for national curriculum policies. Journal of Curriculum Studies, 44(3), 299-321. https://doi.org/10.1080/00220272.2012.668938

Zipke, M. (2018). Preparing teachers to teach with technology: Examining the effectiveness of a course in educational technology. The New Educator, 14(4), 342-362. https://doi.org/10.1080/1547688X.2017.14011 91 